\title{
Dicofol Stimulation of Cell Proliferation
}

K. Du, X. Xu

Research Center for Eco-Environmental Sciences, Chinese Academy of Sciences, 18 Shuang Qing Road, Post Office Box 2871, Beijing 100085, People's Republic of China

Received: 10 May 2000/Accepted: 6 August 2001

The organochlorine pesticides continue to be of public and scientific concerns because they might contribute to raising the risk of breast cancer incidence in several populations through their estrogenic actions. Dicofol (kelthane) (4,4'-Dichloro-alpha-trichloromethyl)benzhydrol), an organochlorine compound used as a miticide, is made from DDT $\left(1,1^{\prime}\right.$ (2,2,2-trichloroethylidene)bis[4-chlorobenzene]). Although some researchers reported that dicofol could induce eggshell changes in a species of the American kestrels (Falco sparverius) (Donald et al. 1989) and had embryonic toxicity in Wister cats (Dai ZZ et al.1987), dicofol is still registered for use as insecticide in many countries including the United States (Zahm and Ward 1998) and China. Dicofol is structurally similar to DDT (see Figure 1) and the commercial product of dicofol contains a certain amount of $o, p^{\prime}$ and $p, p^{\prime}$ isomers of DDT, DDD $\left(1,1^{\prime}-(2,2-\right.$ dichloroethylidene)bis[4-chlorbenzene]) etc. While some isomers of DDT have been shown to have estrogenic actions in vivo as well as in vitro (Bitman and Cecil 1970; Ahlborg et al. 1995; Barton and Andersen 1998), whether the commercial product of dicofol possesses estrogenic potential is not known. The purpose of this study was to determine the cell proliferation potential of $20 \%$ commercial dicofol emulsion in comparison with $17 \beta$-Estradiol.

\section{MATERIALS AND METHODS}

17 \& -Estradiol (purity $>99 \%$ ) was purchased from E. Merck (D-6100 Darmstadt HK). Dicofol commercial emulsion (20\%) used was obtained from official local chemical plant (Changcheng Chemical Plant) with standardized number. Stock solutions of these chemicals were made in absolute ethanol and subsequently diluted to give a final concentration of less than $0.1 \%$ ethanol in culture media. 


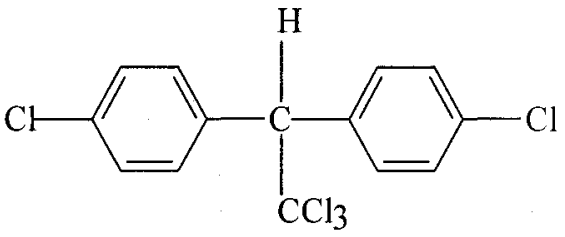

$p, p^{\prime}-\mathrm{DDT}$

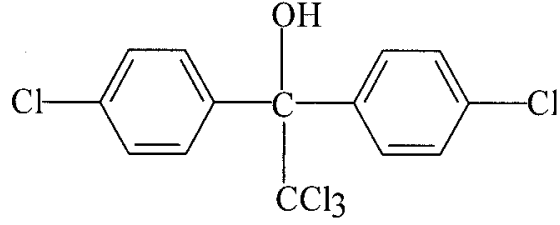

Dicofol

Figure 1. The structure of $p, p^{\prime}$-DDT and dicofol

Table 1. Effect of $20 \%$ commercial dicofol emulsion and $17 \beta$-Estradiol on proliferation of MCF-7 cells

\begin{tabular}{|c|c|c|c|c|}
\hline Samples & ${ }^{\mathrm{a}} \mathrm{CC}$ & ${ }^{b} \mathrm{CN} \times 10^{5}(\mathrm{cells} / \mathrm{mL})$ & $\mathrm{PE}$ & $\mathrm{RPE}$ \\
\hline & \multicolumn{4}{|c|}{ Run 1 the original cell density : $3.2 \times 10^{4}$ cells $/ \mathrm{mL}$} \\
\hline Control & \multicolumn{4}{|c|}{$6.78 \pm 0.41$} \\
\hline & $8.5 \times 10^{-12} \mathrm{~g} / \mathrm{mL}$ & $8.34 \pm 0.96^{*}$ & 1.23 & 1.00 \\
\hline Dic. 1 & $8.0 \times 10^{-12} \mathrm{~g} / \mathrm{mL}$ & $6.31 \pm 1.34^{* *}$ & - & - \\
\hline & \multicolumn{4}{|c|}{ Run 2 the original cell density : $4.4 \times 10^{4}$ cells $/ \mathrm{mL}$} \\
\hline Control & \multicolumn{4}{|c|}{$6.34 \pm 0.39$} \\
\hline $\mathrm{E}_{2}$ & $8.5 \times 10^{-12} \mathrm{~g} / \mathrm{mL}$ & $10.99 \pm 0.31^{*}$ & 1.73 & 1.00 \\
\hline Dic. 2 & $4.0 \times 10^{-11} \mathrm{~g} / \mathrm{mL}$ & $12.90 \pm 0.58^{*}$ & 2.03 & 1.17 \\
\hline Dic. 3 & $4.0 \times 10^{-10} \mathrm{~g} / \mathrm{mL}$ & $13.44 \pm 1.11^{*}$ & 2.12 & 1.23 \\
\hline & \multicolumn{4}{|c|}{ Run 3 the original cell density : $3.6 \times 10^{4}$ cells $/ \mathrm{mL}$} \\
\hline Control & \multicolumn{4}{|c|}{$5.55 \pm 0.66$} \\
\hline$E_{2}$ & $8.5 \times 10^{-12} \mathrm{~g} / \mathrm{mL}$ & $7.71 \pm 0.83^{*}$ & 1.39 & 1.00 \\
\hline Dic.4 & $4.0 \times 10^{-9} \mathrm{~g} / \mathrm{mL}$ & $14.18 \pm 0.58^{*}$ & 2.56 & 1.84 \\
\hline Dic. 5 & $4.0 \times 10^{-8} \mathrm{~g} / \mathrm{mL}$ & $13.45 \pm 0.84^{*}$ & 2.42 & 1.74 \\
\hline Dic. 6 & $4.0 \times 10^{-7} \mathrm{~g} / \mathrm{mL}$ & $12.03 \pm 1.76^{*}$ & 2.17 & 1.56 \\
\hline Dic.7 & $4.0 \times 10^{-6} \mathrm{~g} / \mathrm{mL}$ & $9.86 \pm 0.75^{*}$ & 1.78 & 1.28 \\
\hline Dic. 8 & $4.0 \times 10^{-5} \mathrm{~g} / \mathrm{mL}$ & $x$ & $x$ & $x$ \\
\hline
\end{tabular}

The RPP of $\mathrm{E}_{2}: 1.00$

The RPP of $20 \%$ commercial dicofol emulsion: 0.02

Dic: Dicofol; CC: concentration of compounds; $\mathrm{CN}$ : cell number; $\mathrm{PE}$ : proliferation effect; RPE: relative proliferation effect; RPP: relative proliferation potency; a: the concentration of dicofol per se in samples; $b$ : All the data were mean $\pm S D ; x$ : cells killed at this concentration; $-:$ no positive effect; *: significantly different, $\mathrm{P}<0.001 ;{ }^{* *}$ : not significantly different, $\mathrm{P}>0.05$. 


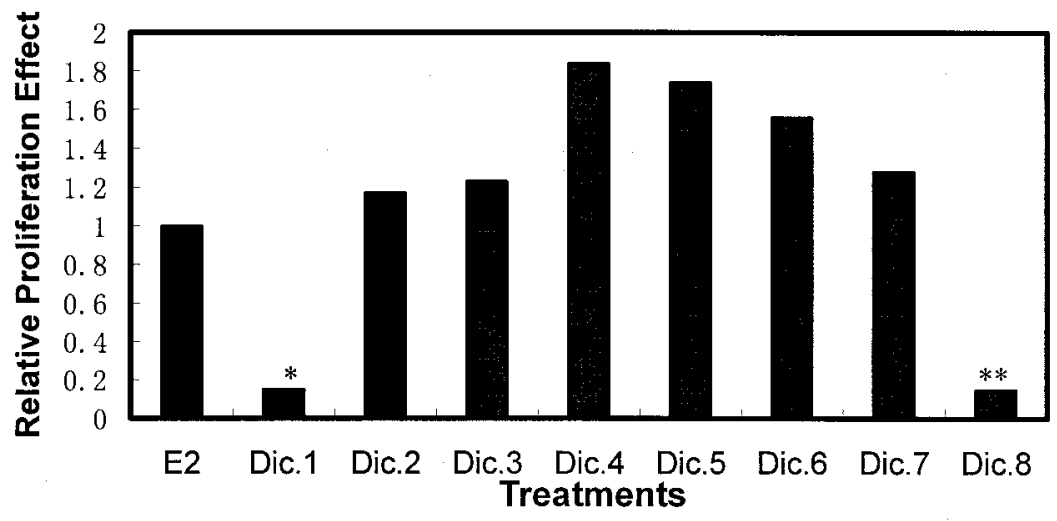

Figure 2. Relative proliferation effect of $20 \%$ commercial dicofol emulsion; Dic: dicofol; ": no positive effect; **: cells killed at this concentration

MCF-7 cell line [American Type Culture Collection (ATCC)] was purchased from the Pathological Laboratory of Beijing Medical University. The cells were grown as monolayer culture in RPMI 1640 medium without phenol red (GIBCO BRL) supplemented with 5\% fetal bovine serum (FBS) and $27 \mathrm{mM}$ HEPES (N-[2-Hydroxyethl]piperazine-N'[2-ethanesulfonic acid]) buffer in a sealed system at $37^{\circ} \mathrm{C}$.

Cell proliferation was measured using the method described by Soto et al (Soto et al. 1985) with slight modification. Cells were trypsinized and plated in culture flasks in 5\% FBS in RPMI 1640 medium. The cells were allowed to attach for $24 \mathrm{hr}$, then $5 \%$ calf serum (the concentration of $E_{2}$ in calf serum was not detected by Automated Chemiluminescence system ACS: 18SE) was substituted for $5 \% \mathrm{FBS}$ in the medium. A range of concentrations of the test compound and $8.5 \times 10^{-12} \mathrm{~g} / \mathrm{mL}$ of $17 \beta$-estradiol and control ethanol vehicle $(0.1 \%)$ were added. The cells were harvested and counted after 6 days.

The E-screen method was used to determine the estrogenic effect of $20 \%$ dicofol commercial emulsion by comparing its relative proliferation effect (RPE) with that of $E_{2}$. The proliferation effect (PE) was defined as the ratio between the highest cell yield obtained with the chemical and with the control. The RPE was the ratio between the PE of the test compound and the PE of $17 \beta$-estradiol, and the relative proliferation potency (RPP) was the ratio between the dose of $E_{2}$ and the dose of test compound needed to produce maximal cell yield (Villalobos et al.1995).

Results were expressed as the means plus or minus standard deviations. 
Each point was the mean of three counts from three culture flasks. Differences between the tested diverse groups were calculated with Student's $t$-test.

\section{RESULTS AND DISCUSSION}

The effects of the $20 \%$ commercial dicofol emulsion and $E_{2}$ on proliferation of MCF-7 cells are shown in Table 1 and Figure 2. Compared to the controls, $20 \%$ commercial dicofol emulsion significantly promoted MCF-7 cell proliferation between $4 \times 10^{-11} \mathrm{~g} / \mathrm{mL}$ to $4 \times 10^{-6} \mathrm{~g} / \mathrm{mL}$ dicofol concentration. At the concentration of $4 \times 10^{-9} \mathrm{~g} / \mathrm{mL}, 20 \%$ commercial dicofol emulsion showed the highest relative proliferation effect. With further increase in concentrations of dicofol from the point of $4 \times 10^{-9} \mathrm{~g} / \mathrm{mL}$, the relative proliferation effects were reduced, while at the concentration of $4 \times 10^{-5} \mathrm{~g} / \mathrm{mL}$ the effect was lost as this concentration was highly toxic to MCF-7 cells. Similar cytotoxicity of dicofol has been reported in human lymphoid cells (Sobti et al. 1983). The relative proliferation effects at each effective concentration were all greater than that of $E_{2}$ at $8.5 \times 10^{-12} \mathrm{~g} / \mathrm{mL}$ concentration.

DDT and related metabolites have been strongly examined on the estrogenic effects (Ahlborg et al. 1995), in vitro test results in MCF-7 cells demonstrated that both $o, p$ ' -DDT and technical grade DDT have estrogenic activity, but approximately one million times less than $17 \beta$ estradiol (Barton et al. 1998), and it was believed that some (perhaps all) of the estrogenic effect are caused by the bindings of DDT and the relative metabolites to the estrogen receptor (Bitman et al. 1970; Ahlborg et al. 1995). $20 \%$ commercial dicofol emulsion expressed very high effect on proliferation of MCF-7 cells, its RPP being 0.02 (see Figure 1) in this study. Moreover, the results of the present study indicate that $20 \%$ commercial dicofol emulsion can enhance proliferation of MCF-7 cells even at low concentration of $4 \times 10^{-}$ ${ }^{11} \mathrm{~g} / \mathrm{mL}$ (Dic.2 in Table 1). The RPE at this concentration of $20 \%$ commercial dicofol emulsion was even slightly greater than that of $E_{2}$ at $8.5 \times 10^{-}$ ${ }^{12} \mathrm{~g} / \mathrm{mL}$ (see Figure 2). Whether it is due to the synergism caused by dicofol, isomers of DDT and other chemicals in emulsion besides the action of dicofol needs further study. However, dicofol should be the key contributor to this high effect and should be given more concern, as it is the main component in the commercial product.

In the present paper, the effect on proliferation of MCF-7 cells was used as an endpoint to analyze the biological effects of $20 \%$ commercial dicofol emulsion. Marked positive effects have been observed with this endpoint test. 
Other cell lines will probably also give interesting results. However, the results obtained from MCF-7 cell line are analogous to our previous report that $20 \%$ commercial dicofol emulsion locally produced significantly elevated uterine weight on immature mice (Zhao et al. 2000).

Acknowledgments. This work was supported by National Natural Science Foundation of China (NO. 29677026, 29837180) and Innovative KIP CAS RCEES 9902-1, 9906.

\section{REFERENCES}

Ahlborg UG, Lipworth L, Titus-ernstoff L, Hsieh C-C, Hanberg A, Baron J, Trichopoulos D, Adami H-O (1995) Organochlorine compounds in relation to breast cancer, endometrial cancer, and endometriosis: an assessment of the biological and epidemiological evidence. Crit Rev Toxicol 25: 463-531

Barton HA, Andersen ME (1998) Endocrine active compounds: from biology to dose response assessment. Crit Rev Toxicol 28: 363-423

Bitman J, Cecil HC (1970) Estrogenic activity of DDT analogs and polychlorinated biphenyls. J Agric Food Chem 18: 1108-1112

Dai ZZ, Zhu SF, Zhang YW, Yang LL (1987) Studies on the teratogenicity and mutagenicity of dicofol. J Prev Med 21: 238-239 (in Chinese)

Donald R, Clark JR, Spann JW, Bunck CM (1989) Dicofol (Kelthane)induced eggshell thinning in captive American kestrels. Environ Toxicol Chem 9: 1063-1069

Sobti RC, Krishan A, Davies J (1983) Cytokinetic and cytogenetic effect of agricultural chemicals on human lymphoid cells in vitro. Arch Toxicol 52: 221-231

Soto AM, Sonnenschein C (1985) The role of estrogen on the proliferation of human breast tumor cells (MCF-7). J Steroid Biochem 23: 87-94.

Villalobos M, Olea N, Brotons JA, Olea-serrano MF, de Almodovar JMR, Pedraza V (1995) The E-Screen assay: a comparison of different MCF7 cell stocks. Environ Health Perspect 103: 844-850

Zahm SH, Ward MH (1998) Pesticides and childhood cancer. Environ Health Perspect 106 (Suppl. 3): 893-908

Zhao BS, Zou JC, Chu SG, Xu XB, Du KJ (2000) Bioassay of estrogenic effect of dicofol using uterine weight method in mice. Acta Scientiae Circumstantiae 20: 244-248 (in Chinese) 